\title{
Beneficiated ponded fly ash for concretes with high volume mineral additions
}

\author{
Nikolai Zaichenko ${ }^{1, *}$, Irina Petrik ${ }^{1}$, and Liudmila Zaichenko ${ }^{1}$ \\ ${ }^{1}$ Donbas National Academy of Civil Engineering and Architecture, 286123 Makeyevka, Ukraine
}

\begin{abstract}
The article presents the investigation results of effect of beneficiated ponded fly ash on the properties of cement pastes and concretes with high-level replacement of Portland cement. To improve the characteristics of ponded fly ash meeting technical requirements for replacing cement in concrete the triboelectrostatic beneficiation technology has been elaborated. This technology can produce low-carbon ash product (LOI $=2.52 \%$ in this study) for the high replacing level of cement $(45 \%)$ in concretes. The beneficiated ponded fly ash has an improved granulometric and phase composition, a decreased content of unburned carbon that accelerates the hydration process of cement, increases the rheological properties of cement paste and the ability of air-entraining admixture to hold the required involved air. In a combination with the nanostructured-carbon-based plasticizing admixture the beneficiated ponded fly ash exhibits high rate of strength increase when is used in highvolume fly ash concretes.
\end{abstract}

\section{Introduction}

Fly ash is a by-product material being generated by thermal power plants from combustion of pulverized coal, and so may be regarded as a waste product $[1,2]$. At thermal power plants, fly ash is presently collected or disposed by using either dry or wet systems. Being cheaper than any other manner of fly ash removal, it is widely used method, thus more than $65 \%$ of fly ash is disposed in landfills and ash ponds [1].

The landfill of fly ash is the problem of all power plants because disposed waste product as a rule is not used in any practical application [3]. The American Coal Ash Association reported that utilization rates for freshly generated fly ash have increased considerably over recent years, with current rates near $60 \%$, however approximately 14 million tons of fly ash continue to be disposed of annually. While utilization rates in Europe have been much higher than in the US, considerable volumes of fly ash have also been stored in landfills [4]. It may cause substantial environmental hazards [5]. Thus, high disposal costs, increased interest in improving the environmental impacts are making fly ash utilization an increasingly attractive alternative to disposal [6].

The utilization of fly ash instead of dumping can be used on economic grounds as pozzolana for partial replacement of cement [7] on the one hand, and because of its

*Corresponding author: zaichenko_nikola@mail.ru 
beneficial effects on the properties of concrete mixtures and concretes [8-10]. However, many variables affect the chemical composition, morphology, and relative phase proportions in fly ash [11]. As a result, the chemical composition in particular the loss-onignition (LOI) content could restrict the amount of fly ash application in cement concretes.

Fly ash particles have a wide size distribution ranging from molecular clusters with diameters of $2 \mathrm{~nm}$ up to particles with diameters of about $100 \mu \mathrm{m}$. The particles larger than $1 \mu \mathrm{m}$ mostly contain unburned mineral materials [12]. In doing so, it was noted that losson-ignition increased with particle size of fly ash samples [13].Beneficiation of fly ash has been studied in recent years and several methods have been proposed to separate good quality cementitious material from the combustible one [14]. However, the electrostatic separation method of unburned carbon from specifically prepared fly ash has the greatest practical significance $[15,16]$. A number of different types of triboelectrostatic separators are known. It was found that the quality of separation is dependent upon the nature of fly ash and the configuration of the separator used [17]. The plate triboelectrostatic separator has been used for this study.

Triboelectrostatic beneficiation of fly ash with high-unburned carbon content can produce low-carbon ash products having value as mineral additions and meeting technical requirements for replacing cement in concrete [18]. This effect is of paramount significance when the beneficiated fly ash will be used in concretes with high volume of mineral additions in particular high-volume fly ash concrete (HVFAC) which contains normally more than $50 \%$ fly ash by mass of total cementitious materials [9]. Nevertheless, while HVFAC can be designed and produced to meet 28-d strength requirements and often exceeds the durability performance of conventional concretes, a persistent problem is the potentially long delay in setting time and hardening process at early curing age $[19,20]$. To overcome these limitations, the next approaches have been proposed by various research teams: the addition of either calcium hydroxide powder $(5 \%)$ or rapid set cement $(5-10 \%)$ [19], silica fume (10\%) and lime (30\%) [21], the replacement of cement with $5 \%$ of nanolimestone [22] or nano- $\mathrm{SiO}_{2}$ [8], the use of ternary blended cements with limestone and Portland cement [7] or high-range water reducing admixtures [23] as well as internal curing to improve hardening process [20]. Belarusian scientists have developed a nanostructuredcarbon-based plasticizing admixture, which makes it possible to produce concrete with exceptional physical-mechanical properties $[24,25]$. Besides, the admixture provides an adequate compressive strength of concrete with addition of fly ash both at early and project ages of hardening. However, the effect of this admixture on the properties of HVFAC has not been investigated. On the other hand, no experimental data regarding concretes with high content of ponded fly ash beneficiated by triboelectrostatic separation technique have previously been reported. Thus, the aim and the objectives of this study are the following: i) to investigate the properties of ponded fly ash treated in the triboelectrostatic separator, ii) to determine the properties of HVFAC with the nanostructured-carbon-based plasticizing admixture and the ponded fly ash beneficiated by triboelectrostatic separation technique.

\section{Experimental}

\subsection{Materials}

Ordinary Portland cement (OPC) CEM I 42.5 N conforming to EN 197-1 and ponded fly ash (PFA) with Blaine specific surface area of 365 and $290 \mathrm{~m}^{2} / \mathrm{kg}$, respectively, were used as cementitious materials. The value of loss-on-ignition of PFA is $6.92 \%$. Quartz sand (fine aggregate FA) with fineness modulus of 2.2 and specific gravity of 2.68 as well as crushed 
granite (coarse aggregate CA) of $10 \mathrm{~mm}$ maximum size and specific gravity of 2.69 were used for producing normal weight concrete.

The nanostructured-carbon-based plasticizing admixture "ART Concrete-K" as an opaque dark brown liquid (superplasticizer based on a polycarboxylate polymer and nanostructured carbon material are in the ratio $100: 0.09 \ldots 0.11)$ has the following properties: dry content $37 \%$, density $1.1 \pm 0.1 \mathrm{~g} / \mathrm{cm}^{3}, \mathrm{pH} 7.0 \pm 1.0$. SikaAer ${ }^{\circledR}$ PRO- 100 admixture was used as a high-efficiency air-entraining agent (AEA) (density 0.995$\left.1.005 \mathrm{~g} / \mathrm{cm}^{3}, \mathrm{pH} 10.0-11.0\right)$.

The formulations of cement-fly ash pastes made with different content of fly ash collected from anode and cathode plates of electrostatic separator as well as with reference ponded fly ash are given in Table 1 . The water to binder ratio was different to evaluate the constant value of standard consistency of the cement-fly ash pastes.

Table 1.The formulations of the cement-fly ash pastes.

\begin{tabular}{|c|c|c|c|c|c|c|c|}
\hline & \multirow{3}{*}{$\begin{array}{l}\text { Formulation } \\
\text { index }\end{array}$} & \multicolumn{5}{|c|}{ Composition } & \multirow{3}{*}{$\mathrm{w} / \mathrm{b}$ ratio } \\
\hline & & \multicolumn{2}{|c|}{$\mathrm{OPC}$} & \multicolumn{2}{|c|}{ PFA } & \multirow{2}{*}{$\begin{array}{c}\text { Water, } \\
\mathrm{ml}\end{array}$} & \\
\hline & & $\mathrm{g}$ & $\%$ & $\mathrm{~g}$ & $\%$ & & \\
\hline 1 & Control & 690 & 100 & 0 & 0 & 172.5 & 0.25 \\
\hline 2 & PFA-anode & 586 & 85 & 104 & 15 & 165.6 & 0.24 \\
\hline 3 & PFA-anode & 380 & 55 & 310 & 45 & 138.0 & 0.20 \\
\hline 4 & PFA-cathode & 586 & 85 & 104 & 15 & 179.4 & 0.26 \\
\hline 5 & PFA-cathode & 380 & 55 & 310 & 45 & 193.2 & 0.28 \\
\hline 6 & PFA-reference & 586 & 85 & 104 & 15 & 200.1 & 0.29 \\
\hline 7 & PFA-reference & 380 & 55 & 310 & 45 & 220.8 & 0.32 \\
\hline
\end{tabular}

\subsection{Experimental procedure}

\subsubsection{Triboelectrostatic separation beneficiation technology}

Ponded fly ash material was dried at $105 \pm 5^{\circ} \mathrm{C}$ and then screened at $315 \mu \mathrm{m}$ as a precursor to further beneficiation. Fly ash particles are mostly composed of silica and alumina, which have a higher work function $\left(\mathrm{SiO}_{2}=5.0 \mathrm{eV}, \mathrm{Al}_{2} \mathrm{O}_{3}=4.7 \mathrm{eV}\right)$ than carbon $(\mathrm{C}=4.0 \mathrm{eV})$. Therefore, when they contact to each other or the surface of copper tribocharger $(\mathrm{Cu}=4.38 \mathrm{eV})$, carbon particles will be charged positively and fly ash particles will be charged negatively due to the differences in the work function values $[6,15]$.

The charged particles enter the separation chamber (Fig. 1) containing the electrodes made of two copper plates attached to its opposite sidewalls. Under the DC electric field generated by a high voltage power supply, the charged particles are deflected towards the electrodes according to their polarity. The electric field ranged from $-2 \mathrm{kV} / \mathrm{cm}$ to $+2 \mathrm{kV} / \mathrm{cm}$.

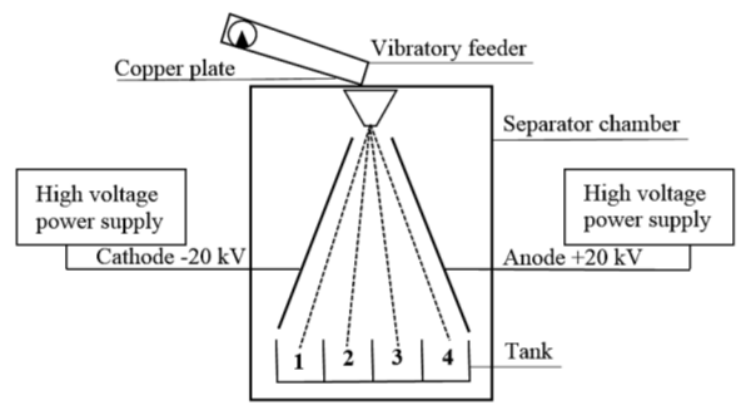

Fig. 1. Schematics of the experimental setup 


\subsubsection{Methods}

The particle size distribution (PSD) of ponded fly ash was determined by the ANALYSETTE 22 Compact laser diffraction particle size analyser.

Loss-on-ignition measurements of fly ash were performed on 1-g samples pre-dried in a laboratory oven at $130^{\circ} \mathrm{C}$ for $2 \mathrm{~h}$ in accordance with ISO 1171-97. After drying, cooling and reweighing, the samples were placed into an air-ventilated laboratory oven at $815 \pm 10^{\circ} \mathrm{C}$ for $2 \mathrm{~h}$ to burn out the residual carbon. The loss in mass at $815^{\circ} \mathrm{C}$ was reported as the LOI, and this is assumed to be the weight of unburned carbon in the original sample.

The Foam Index Test (FIT) was originally designed to evaluate the influence of cementitious materials on the air-entraining capacity of concrete [26]. At first, $20 \mathrm{~g}$ of Portland cement were placed in a $125 \mathrm{ml}$ glass jar. Then $50 \mathrm{ml}$ of water were added to the jar which was caped and shaken for a minute. Diluted AEA solution (50 ml AEA : $50 \mathrm{ml}$ water) was added in small increments of 2 to 5 drops at a time. After each addition, the jar was shaken vigorously for 15 seconds. The stability of the foam was observed. The minimum amount of diluted AEA needed to produce a foam that is stable (bubbles exist over the entire surface) for 45 seconds is the Foam Index of the cement mixture. After that, the steps 1 through 4 using different proportions of cement and fly ash to develop the foam index of the cement and fly ash mixture were repeated [27].

Diffraction studies of the ponded fly ash samples were conducted with the help of 26 ARLX'TRA X-ray diffractometer (ARL, Switzerland) using $\mathrm{CuK}_{\alpha}$ radiation $(\lambda=1.54056 \AA)$ at a voltage of $40 \mathrm{kV}$ and a current of $20 \mathrm{~mA}$. The scanning was carried in 4 to 70 degrees 2 -theta range with a step of 0.02 degrees. X-ray phase analysis of the cement-fly ash pastes was performed on the X-ray diffractometer DRON-4-07. The diffraction patterns were recorded at a wavelength of $\lambda=1.54178 \AA$ in a step-by-step mode $\left(2 \theta=15-75^{\circ}\right.$ with a step of $0.1^{\circ}$ and exposure time of $\left.5 \mathrm{~s}\right)$ at $27 \mathrm{kV}, 15 \mathrm{~mA}$.

Vicat apparatus mold was used to determine the standard consistency of cement paste. Cubes $50 \times 50 \times 50 \mathrm{~mm}$ and $100 \times 100 \times 100 \mathrm{~mm}$ were used to evaluate the compressive strength of cement paste and concrete, respectively. Tests were conducted at different test age: 3,7 , and 28 days.

\section{Results and discussion}

\subsection{Properties of the beneficiated ponded fly ash}

\subsubsection{Particle size distribution and loss-on-ignition}

The particle size distribution curves for six samples of ponded fly ash collected after the electrostatic separation from each cell of tanker (1-4) and plate electrodes (A, C) of the experimental setup (Fig. 1) are given in Fig. 2.

The curves of the samples from tanker cells show approximately the same particle size distribution over the range between 0.3 and $300 \mu \mathrm{m}$ while the curves of the samples from electrodes are over the more narrow range: $0.3-100 \mu \mathrm{m}$ (anode) and 0.3-200 $\mu \mathrm{m}$ (cathode). Besides, the PSD analysis indicates that the mass median diameter is the smallest for the samples collected from the plate electrodes: $19.89 \mu \mathrm{m}$ (cathode), $17.93 \mu \mathrm{m}$ (anode) and decreases from the cells of cathode zone to anode one (Table 2). The highest content of the particles less than $2 \mu \mathrm{m}$ is observed near the anode zone respectively. On the other hand, the cells 3 and 4, which are near the zone of anode contain the particles with maximum size $\mathrm{d}_{98}=151.1$ and $142.3 \mu \mathrm{m}$, respectively. Obviously, as it was pointed out earlier large particles of fly ash mostly contain unburned mineral material. 

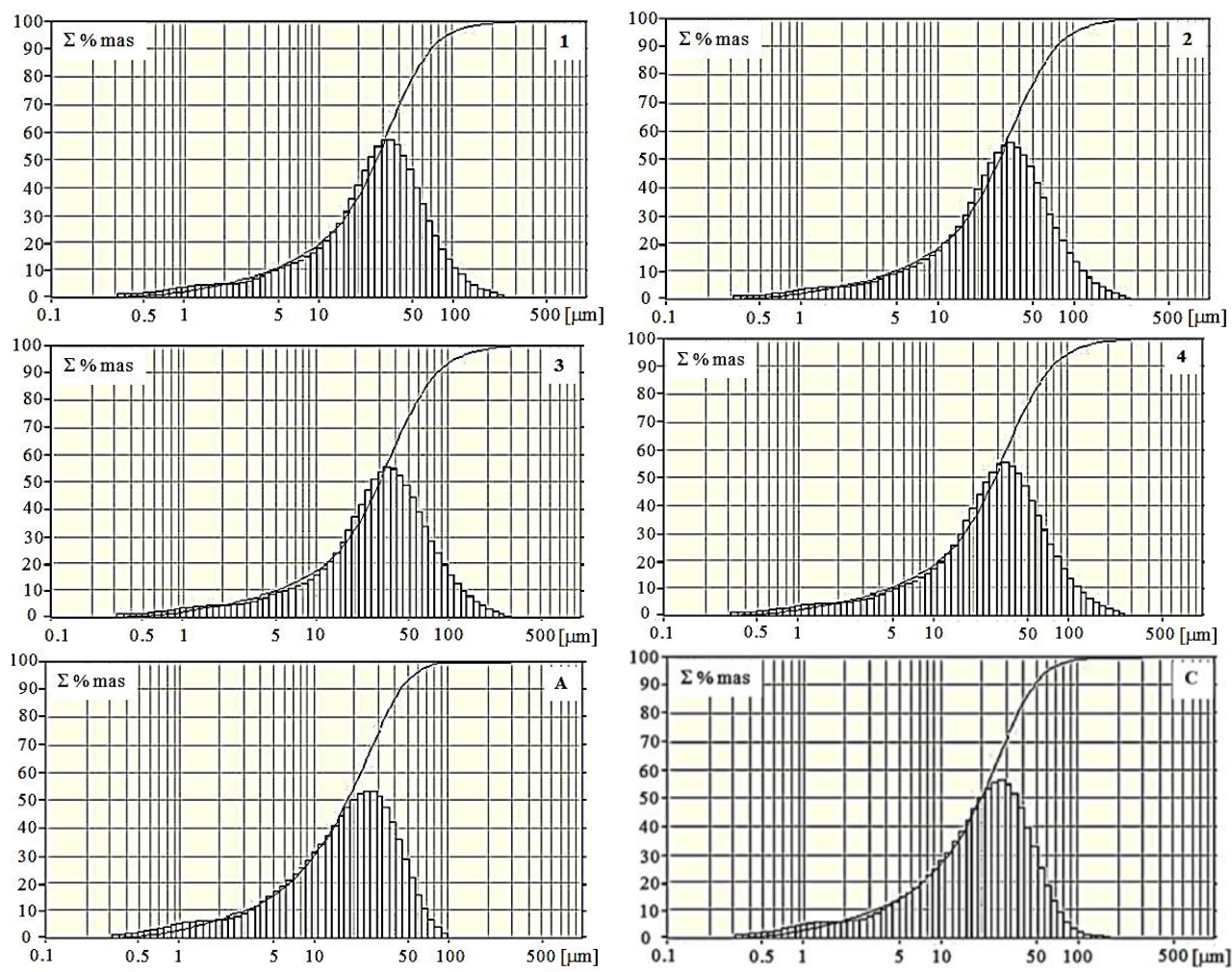

Fig. 2. Particle size composition and cumulative particle size distribution of ponded fly ash.

Table 2. Particle size and loss-on-ignition data for yields obtained after triboelectrostatic separation of PFA.

\begin{tabular}{|c|c|c|c|c|c|c|c|c|}
\hline \multirow{2}{*}{$\begin{array}{l}\text { Sample - } \\
\text { zone of } \\
\text { separator }\end{array}$} & \multicolumn{2}{|c|}{ Yield } & \multicolumn{2}{|c|}{ Particles size, $\mu \mathrm{m}$} & \multirow{2}{*}{$\begin{array}{l}\text { Particles } \\
\text { less than } \\
2 \mu \mathrm{m}, \%\end{array}$} & \multicolumn{3}{|c|}{ LOI } \\
\hline & $\mathrm{g}$ & $\%$ & $\begin{array}{c}\operatorname{maximum}_{\mathrm{d}_{98}}\end{array}$ & $\begin{array}{l}\text { median } \\
\mathrm{d}_{50}\end{array}$ & & $\mathrm{~g}$ & $\begin{array}{c}\% \\
\text { yield }\end{array}$ & $\begin{array}{c}\text { \%total } \\
\text { mass }\end{array}$ \\
\hline Cathode (C) & 15 & 1.5 & 76.461 & 19.891 & 7.64 & 3.3 & 22.0 & 4.8 \\
\hline 1 & 45 & 4.5 & 123.972 & 27.302 & 6.17 & 21.5 & 47.8 & 31.1 \\
\hline 2 & 113 & 11.3 & 134.805 & 28.592 & 5.89 & 19.2 & 17.0 & 27.7 \\
\hline 3 & 276 & 27.6 & 151.125 & 26.546 & 5.75 & 11.4 & 4.1 & 16.5 \\
\hline 4 & 482 & 48.2 & 142.337 & 25.859 & 6.96 & 12.3 & 2.6 & 17.8 \\
\hline Anode (A) & 69 & 6.9 & 66.576 & 17.930 & 8.01 & 1.5 & 2.2 & 2.1 \\
\hline Total & 1000 & 100 & & & & 69.2 & & 100 \\
\hline
\end{tabular}

Theoretically taking into account the positive electric charge of carbon, its particles should be deflected towards the electrode according to their polarity, i.e. towards cathode. However, the data represented in Table 2 provide evidence of the existence of quite high content of LOI ( $17.3 \%$ of total yield of PFA after separation) within the range of positive electric field (anode, cells 4-3). This could be explained by the following approach. Electrostatic separation must be carried out on dry material, as fly ash and unburned carbon cannot be charged and separated in wet form due to capillary cohesion forces. Researches, carried out on electrostatic carbon removal of wet-stored (ponded) fly ash after drying, have found that a charge reversal of carbon occurs $[4,18,28]$. It is necessary to mention, that the mechanism that changes the relative work function and thus contact-charging behavior of the material nevertheless has been not yet understood. One suggested mechanism is the 
redistribution of soluble ions on the surface of carbon particles, possibly further influenced by the $\mathrm{pH}$ of the aqueous solution on the ash [4].

\subsubsection{Phase analysis}

The crystalline components of ponded fly ash have been characterized by using X-ray powder diffraction. The main crystalline phases detected from XRD (Fig. 3) are quartz $\left(\mathrm{SiO}_{2}\right)\left(\mathrm{d}=0.334 \mathrm{~nm}, 2 \theta=26.64^{\circ} ; \mathrm{d}=0.228 \mathrm{~nm}, 2 \theta=39.49^{\circ} ; \mathrm{d}=0.165 \mathrm{~nm}, 2 \theta=55.65^{\circ}\right)$ and hematite $\left(\mathrm{Fe}_{2} \mathrm{O}_{3}\right)\left(\mathrm{d}=0.240 \mathrm{~nm}, 2 \theta=37.44^{\circ} ; \mathrm{d}=0.184 \mathrm{~nm}, 2 \theta=49.49^{\circ}\right)$. The broad "halo", centered at approximately $2 \theta=26.5^{\circ}$ on the diffractograms suggests the presence of a large amount of amorphous material.

The proportions of each of the crystalline phase and the bulk amorphous material determined for the six samples of PFA collected from different zones of the triboelectrostatic separator are reported in Table 3. Evidence from XRD analysis indicates that all samples of PFA are identical in the bulk amorphous material. The differences in the content of the crystalline phases are of a minor nature. In particular, the highest amount of quartz along with the smallest amount of hematite are in the cells located in the operation zone of anode electrode. This could beneficiate the fly ash as pozzolana since ultrafine particles of quartz may exhibit pozzolanic properties as well as play the role of nucleation centers.

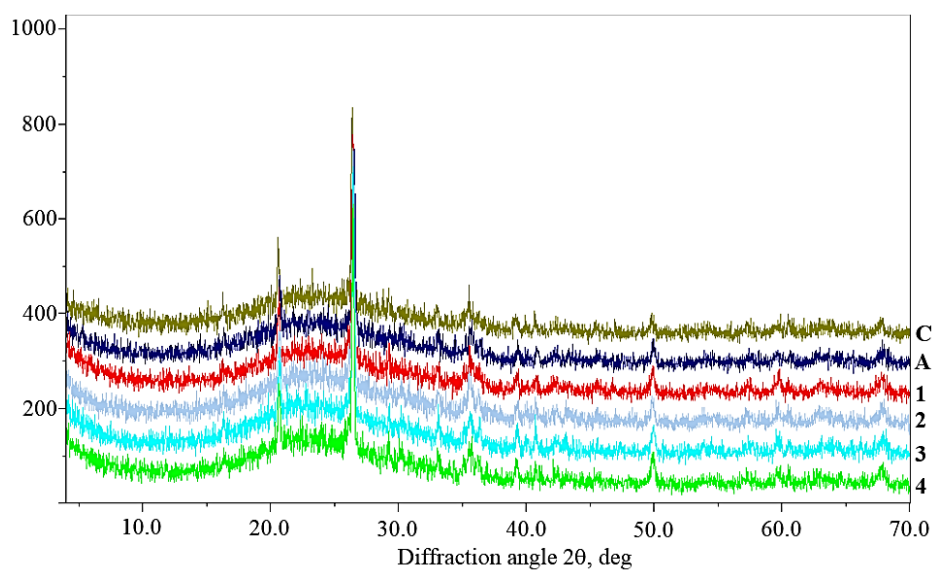

Fig. 3. Diffractograms of ponded fly ash after triboelectrostatic separation.

Table 3. Proportions of crystalline phases and bulk amorphous material presented in PFA.

\begin{tabular}{|c|c|c|c|}
\hline \multirow{2}{*}{$\begin{array}{c}\text { Sample - zone } \\
\text { of separator }\end{array}$} & \multicolumn{3}{|c|}{ Content, \% } \\
\cline { 2 - 4 } quartz & hematite & amorphous phase \\
\hline Cathode (C) & 19.7 & 5.3 & 75.0 \\
1 & 20.9 & 4.1 & 75.0 \\
2 & 19.0 & 6.0 & 75.0 \\
3 & 20.0 & 5.0 & 75.0 \\
4 & 21.2 & 3.8 & 75.0 \\
Anode (A) & 21.9 & 3.1 & 75.0 \\
\hline
\end{tabular}

\subsubsection{Foam index}

When a fly ash addition contains a large amount of carbon, the adsorption of the AEA surfactant by the carbon destroys the ability of concrete to hold the required involved air. 
This adsorption problem dictates the rejection of large amounts of commercial utility ash [29]. Thus, decreasing content of LOI is one of the key factors to beneficiate low-quality fly ash, in particular ponded fly ash.

Table 4 shows the change in air-entraining admixture requirement during the foam index test. The cement-fly ash proportions were made up in such a way that when the ash content is over the range between 15 and $60 \%$, the amount of unburned carbon in the samples of ash taken from different zones of the triboelectrostatic separator ranged from 1.32 to $7.17 \%$.

Table 4. Proportions of cement-fly ash mixtures and foam index.

\begin{tabular}{|c|c|c|c|c|c|c|c|}
\hline \multirow{2}{*}{ Sample } & \multicolumn{2}{|c|}{ OPC } & \multicolumn{3}{c|}{ PFA } & \multirow{2}{*}{ Water, ml } & Solution of \\
\cline { 2 - 5 } & $\%$ & $\mathrm{~g}$ & $\%$ & $\mathrm{~g}$ & LOI, $\mathrm{m}$ & & $\mathrm{ml}$ \\
\hline Anode (A) & 40 & 8 & 60 & 12 & 0.264 & 50 & 0.20 \\
4 & 45 & 9 & 55 & 11 & 0.286 & 50 & 0.25 \\
3 & 50 & 10 & 50 & 10 & 0.410 & 50 & 0.33 \\
Reference (R) & 55 & 11 & 45 & 9 & 0.621 & 50 & 0.55 \\
2 & 65 & 13 & 35 & 7 & 1.190 & 50 & 0.96 \\
Cathode (C) & 70 & 14 & 30 & 6 & 1.320 & 50 & 1.62 \\
1 & 85 & 17 & 15 & 3 & 1.434 & 50 & 1.82 \\
\hline
\end{tabular}

It follows from the data of Table 4 that a high amount of unburned carbon (LOI) affects the required dosage of air-entraining admixture significantly but not a high content of fly ash. The higher LOI content in the fly ash sample the higher the amount of diluted AEA is needed to produce stable foam.

\subsection{Properties of the Portland cement - beneficiated ponded fly ash pastes}

\subsubsection{Compressive strength}

The compressive strength results are given in Table 5. It can be observed that compressive strength of the Portland cement-fly ash pastes of all formulations increases with curing age. Besides, strength increment of samples with partial replacement of Portland cement by ponded fly ash as compared with control formulation (100\% OPC) increases with curing age. Thus, for example, the paste formulation with $15 \%$ replacement of OPC by beneficiated PFA (sample from anode) possesses the following percentage of compressive strength at the age of 3, 7, and 28 days - 87.6, 103.9, and $106.7 \%$, respectively. Nevertheless, the retardation effect of PFA on the 3-d early compressive strength is clear observed.

Table 5. Compressive strength of cement pastes.

\begin{tabular}{|c|c|c|c|c|c|c|}
\hline \multirow{2}{*}{\multicolumn{2}{|c|}{$\begin{array}{l}\text { Formulation } \\
\text { index }\end{array}$}} & \multirow{2}{*}{$\mathrm{w} / \mathrm{b}$} & \multirow{2}{*}{ PFA, \% } & \multicolumn{3}{|c|}{ Compressive strength, MPa (\%) } \\
\hline & & & & $3-d$ & $7-d$ & $28-d$ \\
\hline 1 & Control & 0.25 & 0 & $26.6(100)$ & $51.9(100)$ & $66.7(100)$ \\
\hline 2 & PFA-anode & 0.24 & 15 & $23.3(87.6)$ & $53.9(103.9)$ & $71.2(106.7)$ \\
\hline 3 & PFA-anode & 0.20 & 45 & $17.7(66.5)$ & $35.8(68.9)$ & $56.8(85.2)$ \\
\hline 4 & PFA-cathode & 0.26 & 15 & $19.2(72.2)$ & $41.6(80.2)$ & $52.1(78.1)$ \\
\hline 5 & PFA-cathode & 0.28 & 45 & $15.5(58.3)$ & $31.3(60.3)$ & $41.9(62.8)$ \\
\hline 6 & PFA-reference & 0.29 & 15 & $17.2(64.7)$ & $34.4(66.3)$ & $44.8(67.2)$ \\
\hline 7 & PFA-reference & 0.32 & 45 & $12.2(45.9)$ & $26.7(51.4)$ & $39.7(59.5)$ \\
\hline
\end{tabular}

As pozzolanic reaction is a slow process that its contribution to strength occurs only at later ages, the early strength of cement paste will be significantly reduced if a large amount of fly ash is used [8]. It can be seen that at the age of 28 days the formulation with $15 \%$ 
beneficiated PFA (sample from anode) as a partial replacement of OPC has the compressive strength value $6.7 \%$ higher as compared with the control sample. When the replacement level is $45 \%$ (sample from anode) the 28 -d compressive strength is high enough $(85.2 \%)$ too. First and foremost, this is due to the beneficiated characteristics of ponded fly ash after the triboelectrostatic separation process, in particular decreased LOI content, improved granulometric and phase composition that are responsible for the improved rheological properties of fresh pastes (decreased w/b ratio). In this case, the fly-ash particles can act as "ball-bearing" to better the rheological properties of fresh pastes [10].

\subsubsection{Influence of the fly ash addition on cement paste hydration}

According to the XRD analysis (Fig. 4), it has been found that PFA affects the hydration of cement clinker minerals in particular tricalcium silicate (alite). It can be illustrated by the relative intensity of the most indicative diffraction peaks in the composition of cement pastes with equal level replacement of OPC by PFA. For instance, the relative intensity (as compared with control sample) of the cement pastes with $15 \%$ replacement CP-2, CP-4, and CP-6, respectively: $d=0.278 \mathrm{~nm}\left(2 \theta=32.17^{\circ}\right)-85.6,93.4,87.9 \% ; d=0.177 \mathrm{~nm}$ $\left(2 \theta=51.59^{\circ}\right)-84.4,94.3,88.1 \% ; \mathrm{d}=0.164 \mathrm{~nm}\left(2 \theta=56.00^{\circ}\right)-91.3,102.2,113.9 \% . \mathrm{A}$ similar pattern holds for the cement pastes containing $45 \%$ PFA: CP-3, CP-5, and CP-7, respectively: $\mathrm{d}=0.278 \mathrm{~nm}-81.8,90.7,93.1 \% ; \mathrm{d}=0.177 \mathrm{~nm}-96.3,106.7,96.2 \%$; $\mathrm{d}=0.164 \mathrm{~nm}-107.3,113.8$, and $120.4 \%$.

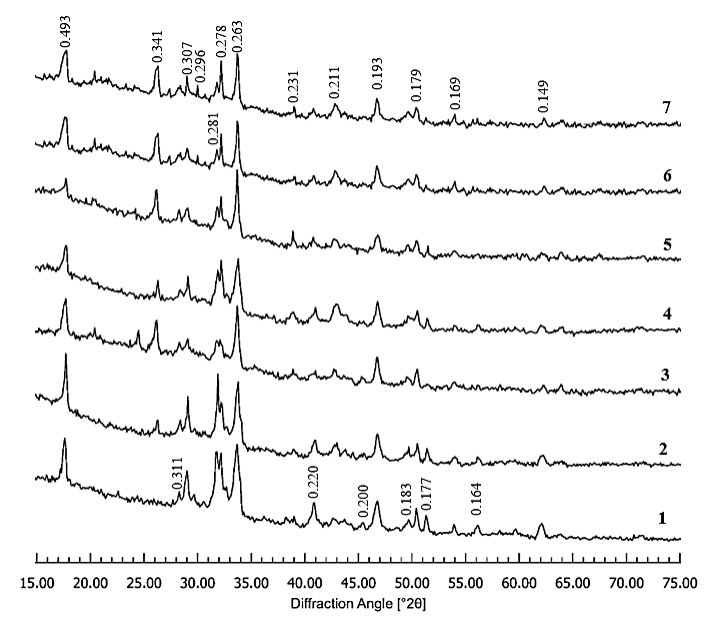

Fig.4. XRD patterns of cement pastes with addition of PFA.

Figure 4 also gives the variations in the relative intensity of the Portlandite $(\mathrm{CH})$ diffraction peaks: $d=0.493 \mathrm{~nm}\left(2 \theta=17.98^{\circ}\right), d=0.311 \mathrm{~nm}\left(2 \theta=28.66^{\circ}\right), d=0.263 \mathrm{~nm}$ $\left(2 \theta=34.05^{\circ}\right)$ as well as calcium hydrosilicate phases $\left(\mathrm{CSH}(\mathrm{B})\right.$ and $\left.\mathrm{C}_{2} \mathrm{SH}_{2}\right): \mathrm{d}=0.307 \mathrm{~nm}$ $\left(2 \theta=29.06^{\circ}\right), \quad d=0.281 \mathrm{~nm} \quad\left(2 \theta=31.82^{\circ}\right), \quad d=0.183 \mathrm{~nm} \quad\left(2 \theta=49.79^{\circ}\right) ; \quad d=0.220 \mathrm{~nm}$ $\left(2 \theta=40.99^{\circ}\right), \mathrm{d}=0.211 \mathrm{~nm}\left(2 \theta=42.90^{\circ}\right), \mathrm{d}=0.200 \mathrm{~nm}\left(2 \theta=45.31^{\circ}\right)$. The results indicate that PFA collected from the anode plate is more reactive as compared with the samples from the cathode plate as well as the reference PFA.

\subsection{Properties of HVFAC}

The formulations and the properties of HVFAC made with ponded fly ash collected from the different zones of the triboelectrostatic separator as well as with the reference ponded 
fly ash are given in Table 6 . The replacement level of OPC by PFA was $45 \%$ and the slump of concrete mixtures got corresponded to the class S2 in accordance with EN 206-1 by means of the $\mathrm{w} / \mathrm{b}$ ratio of concrete.

Table 6.Mixture proportions and test results.

\begin{tabular}{|c|c|c|c|c|c|c|c|c|c|c|c|}
\hline \multirow{2}{*}{ Sample } & \multicolumn{8}{|c|}{ Mixture proportions, $\mathrm{kg} / \mathrm{m}^{3}$} & \multirow{2}{*}{$\begin{array}{c}\mathrm{S}, \\
\mathrm{mm}\end{array}$} & \multicolumn{2}{|c|}{$f_{c,}, \mathrm{MPa}$} \\
\hline & $\mathrm{OPC}$ & PFA & $\mathrm{CA}$ & FA & $\mathrm{A} 1,1$ & $\mathrm{~A} 2,1$ & $\mathrm{w} / \mathrm{b}$ & $\mathrm{AC}, \%$ & & 7 & 28 \\
\hline $\mathrm{C}$ & 500 & 0 & 1080 & 605 & 0 & 0 & 0.40 & 1.14 & 5.5 & 29.3 & 48.4 \\
\hline A-4-3 & 275 & 225 & 920 & 719 & 5.0 & 3.5 & 0.28 & 5.88 & 7.3 & 31.7 & 53.8 \\
\hline $\mathrm{C}-2-1$ & 275 & 225 & 946 & 740 & 5.0 & 3.5 & 0.28 & 4.13 & 6.4 & 22.6 & 45.2 \\
\hline $\mathrm{R}$ & 275 & 225 & 954 & 747 & 5.0 & 3.5 & 0.28 & 3.56 & 5.2 & 20.5 & 41.4 \\
\hline
\end{tabular}

Keys: $\mathrm{C}=$ control concrete; A-4-3 = concrete with PFA from anode and 4-3 cells of the triboelectrostatic separator tank; C-2-1 = concrete with PFA from cathode and 2-1 cells; $\mathrm{R}=$ concrete with reference PFA; A1 = "ART Concrete-K" admixture; A2 = SikaAer ${ }^{\circledR} P R O-100$ admixture; $\mathrm{AC}=$ air content; $\mathrm{S}=$ consistence of concrete (slump); $f_{\mathrm{c}}=$ compressive strength of concrete.

It can be seen from the data of Table 6 that concrete mixtures with equal content of the reference ponded fly ash (R) and PFA collected from different zones of the triboelectrostatic separator (A-4-3 and C-2-1) possess distinct properties, in particular air content and slump. Obviously, the A-4-3 sample containing the beneficiated ponded fly ash with LOI of $2.52 \%$ has the highest values. On the other hand, the capacity of the airentraining admixture decreases with increasing content of LOI $-4.40 \%(\mathrm{C}-2-1)$ and $6.92 \%(\mathrm{R})$. Besides, the increased content of LOI adversely affects the slump of concrete mixtures.

The concrete sample containing the beneficiated PFA (A-4-3) and the nanostructuredcarbon-based plasticizing admixture exhibited high rate of strength increase: $31.7 \mathrm{MPa}$ (8.2\% increment as compared with control sample) as soon as after 7 days of curing and $53.8 \mathrm{MPa}(\Delta=11.2 \%)$ after 28 days.

\section{Conclusions}

From the results of this study, it is possible to conclude that triboelectrostatic beneficiation of ponded fly ash with increased-unburned carbon content $(\mathrm{LOI}=6.92 \%$ ) can produce low-carbon ash product $(\mathrm{LOI}=2.52 \%)$ meeting technical requirements for the high replacing level of cement $(45 \%)$ in concretes. The beneficiated ponded fly ash has an improved granulometric and phase composition, a decreased content of unburned carbon that accelerates the hydration process of cement, increases the rheological properties of cement paste and the ability of AEA to hold the required involved air. In a combination with the nanostructured-carbon-based plasticizing admixture the beneficiated PFA exhibits high rate of strength increase when is used in HVFAC.

The authors appreciate the National Research Moscow State University of Civil Engineering (NRU MGSU) for providing the opportunity to carry out this research.

\section{References}

1. I. Nawaz, IJIRSET, 2, 10, pp. 5259-5266 (2013)

2. K. L. Scrivener, V. M. John, E. M. Gartner, Cem. Concr. Res., 114, pp. 2-26 (2018)

3. R. Cheerarot, C. Jaturapitakkul, Waste Manage.,24, 7, pp. 701-709 (2004)

4. L. Baker, A. Gupta, F. Hrach, 2019 World of Coal Ash (WOCA) Conference in St. Louis, Missouri (2019) 
5. H. Chung-Ho, L. Shu-Ken, C. Chao-Shun, C. How-Ji, Constr. Build. Mater., 46, pp. 71-78 (2013)

6. F. Cangialosi, M. Notarnicola, L. Liberti, P. Caramuscio, G. Belz, T.Z. Gurupira, J.M. Stencel, Fuel, 85, pp. 2286-2293 (2006)

7. S. Donatello, C. Kuenzel, A. Palomo, A. Fernández-Jiméneza, Cem. Concr. Comp., 45, pp. 234-242 (2014)

8. G. Li, Cem. Concr. Res., 34, 6, pp. 1043-1049 (2004)

9. R. Siddique, Cem. Concr. Res., 34, 3, pp. 487-493 (2004)

10. Q. Zeng, K. Li, T. Fen-Chong, P. Dangla, Cem. Concr. Res., 42, 1, pp. 194-204 (2012)

11. R. T. Chancey, P. Stutzman, M. C. G. Juenger, D. W. Fowler, Cem. Concr. Res., 40, 1, pp. 146-156 (2010)

12. J.-H. Ji, J. Hwang, G.-N. Bae, Y.-G. Kim, J. Electrostatics, 61, pp. 57-68 (2004)

13. C. J. Badenhorst, N. J. Wagner, B. R. V. Valentim, K. S. Viljoen, A. C. Santos, A. Guedes, CCGP J., 11, pp. 89-96 (2019)

14. A. Antoni, V. Satrya, H. Djwantoro, CED, 17, 1, pp. 38-43 (2015)

15. F. Cangialosi, F. Crapulli, G. Intini, L. Liberti, M. Notarnicola, WIT Transac. Ecol. \& Environ., 92 (2006)

16. K. Wierzchowski, B. Białecka, J. Calus Moszko, A. Klupa, Int. J. Environ. Sci. Technol. (2020)

17. Y. Soong, M. R. Schoffstall, T. A. Link, Fuel, 80, 6, pp. 879-884 (2001)

18. F. Cangialosi, M. Notarnicola, L. Liberti, J. Stencel,J. Hazard Mater., 164, (2-3), pp. 683-688 (2009)

19. D. P. Bentz, C. F.Ferraris, Cem. Concr. Comp., 32, 4, pp. 265-270 (2010)

20. I. De la Varga, R. P. Spragg, C. Di Bella, J. Castro, D. P. Bentz, J. Weiss, Cem. Concr. Comp., 45, pp. 102-110 (2014)

21. Ch. Mounika, V. Srinivasa Reddy, M. V. Seshagiri Rao, S. Shrihari, Int. J. Recent Technol. Eng., 8, 3, pp. 5289-5293 (2019)

22. D. P. Bentz, T. Sato, I. De la Varga, W. J. Weiss, Cem. Concr. Comp., 34, 1, pp. 11-17 (2012)

23. A. Durán-Herrera, C. A. Juarez, P. Valdez, D. P. Bentz, Cem. Concr. Comp., 33, 1, pp. 39-45 (2011)

24. S. A. Zhdanok, E. N. Polonina, S. N. Leonovich, et al., J. Eng. Phys. Thermophy., 92, 4, pp. 376-382 (2019)

25. S. A. Zhdanok, E. N. Polonina, S. N. Leonovich, et al., J. Eng. Phys. Thermophy., 92, 4, pp. 12-18 (2019)

26. J. P. Baltrus, R. B. LaCount, Cem. Concr. Res., 31, 5, pp. 819-824 (2001)

27. The foam index test: a rapid indicator of relative AEA demand, Tech Bulletin, GCP Applied Technologies Inc, USA, 2016

28. M. J. McCarthy, M. R. Jones, T. A. Hope, R. A. Carroll, N. Cooke, Innovative processing of stockpile fly ash (Working Draft Report, University of Dundee, 2019)

29. I. Külaots, A. Hsu, R. H. Hurt, E. M. Suuberg, Cem. Concr. Res., 33, 12, pp. 2091 2099 (2003) 